\title{
STRATEGI GURU DALAM PEMBELAJARAN AL-QUR'AN MELALUI E-LEARNIG DI SDN PADA GUGUS 8 CAKUNG JAKARTA TIMUR
}

\author{
NINGATINI \\ Universitas Muhammadiyah Jakarta \\ Email : ningmazaya@gmail.com
}

\begin{abstract}
ABSTRAK
Keberhasilan sebuah pembelajaran tidak lepas dari strategi guru dalam memberikan sebuah pembelajaran. Seorang guru harus mampu memberikan pembelajaran untuk meningkatkan potensi dan kecerdasan anak didik. Guru harus tetap semangat memberikan pembelajaran walaupun secara E-learning, dan tidak terkecuali pembelajaran Al-Qur'an. Tujuan penelitian ini adalah untuk mengetahui strategi guru dalam pembelajaran Al-Qur'an melalui E-learning di SDN pada Gugus 8 Cakung Jakarta Timur, mengetahui faktor pendukung dan kendala yang dihadapi serta cara mengatasi kendala tersebut. Penelitian ini menggunakan pendekatan kualitatif deskriptif. Teknik pengumpulan data melalui observasi partisipan, wawancara mendalam, serta dokumentasi. Subyek penelitiannya adalah kepala sekolah dan guru Pendidikan agama Islam.Hasil penelitian ini menunjukkan bahwa: Strategi guru dalam pembelajaran Al-Qur'an melalui E-learning merupakan langkah-langkah guru dalam pembelajaran melalui media whatsapp maupun melalui aplikasi zoom meeting. Faktor pendukung pembelajaran Al-Qur'an melalui E-learning adalah: a) Tersedianya sarana seperti kepemilikan ponsel atau laptop dan jaringan internet. b) Kemampuan dan kemauan guru dan anak didik dalam mengoperasikannya. c) Kerjasama yang baik dengan orangtua dalam pendampingan dan bimbingan, d) Keikutsertaan anak didik dalam pembelajaran Al-Quran baik di Taman Pendidikan Al-Qur'an (TPA). Kendala yang dihadapi guru dalam pembelajaran dan solusi yang diterapkan adalah terdapat beberapa anak yang tidak memiliki ponsel atau laptop dan jaringan internet. Adapun solusi yang diterapkan adalah memberikan arahan atau anjuran pada anak didik untuk belajar bersama teman terdekat yang dapat mengikuti pembelajaran secara E-learning, dan memberikan kelonggaran waktu dalam mengirimkan hasil belajar
\end{abstract}

Kata Kunci: Strategi guru, Pembelajaran Al-Qur'an, Pandemi Covid-19, E-learning

ABSTRACT

The success of a lesson cannot be separated from the teacher's strategy in providing a lesson. A teacher must be able to provide learning to increase the potential and intelligence of students. Teachers must keep the spirit of providing learning even though it is e-learning, and learning the Qur'an is no exception. The purpose of this study was to determine the teacher's strategy in learning the Qur'an through E-learning at SDN in Cluster 8 Cakung, East Jakarta, to find out the supporting factors and obstacles faced and how to overcome these obstacles. This study uses a descriptive qualitative approach. Data collection techniques through participant observation, in-depth interviews, and documentation. The research subjects are principals and teachers of Islamic religious education. The results of this study indicate that: The teacher's strategy in learning the Qur'an through E-learning is the teacher's steps in learning through whatsapp media or through the zoom meeting application. The supporting factors for learning the Qur'an through E-learning are: a) Availability of facilities such as ownership of a cellphone or laptop and an internet network. b) The ability and willingness of teachers and students to operate it. c) Good cooperation with parents in mentoring and guidance, d) Participation of students in learning Al-Quran both in the Al-Qur'an Education Park (TPA). The obstacle faced by the teacher in learning and the solution applied was that there were some children who did not have a cellphone or laptop and an internet network. The solution applied is to provide direction or advice to students to study with their closest friends who can participate in Elearning learning, and provide time leeway in sending learning outcomes.

Keywords: Teacher strategy, Al-Qur'an learning, Covid-19 pandemic, E-learning 


\section{PENDAHULUAN}

Guru atau Pendidik merupakan salah satu faktor penting dan juga penentu dalam pendidikan, karena guru mempunyai tanggung jawab yang besar dalam membentuk watak, perangai, tingkah laku dan kepribadian peserta didik. Sedangkan menurut istilah yang sering dipergunakan bagi pendidik adalah guru. Guru sering diidentifikasikan kepada pengertian pendidik. Hal ini sesuai dengan pendapat yang dikemukakan oleh Sardiman, bahwa guru memang pendidik, sebab dalam pekerjaannya ia tidak hanya mengajar seseorang agar tahu beberapa hal, tetapi guru juga melatih beberapa keterampilan dan sikap mental peserta didik (Sardiman, 1990).

Strategi guru dalam pembelajaran merupakan rencana tindakan (rangkaian kegiatan) termasuk dalam penggunaan metode dan pemanfaatan berbagaai sumber kekuatan dalam pembelajaran. strategi guru dalam pembelajaran disusun untuk mencapai tujuan tersebut. Dengan demikian penyusunan langkah-langkah pembelajaran dengan pemanfaatan berbagai fasilitas dan sumber belajar semuanya digunakan dalam upaya mencapai tujuan pembelajaran (Wina sanjaya, 2005). Dari pendapat tersebut sehingga dapat dikatakan strategi mengajar adalah tindakan nyata dari guru atau merupakan praktik guru melaksanakan pengajaran melalui cara tertentu yang dinilai lebih efektif dan efisien. Dengan kata lain, strategi mengajar adalah politik atau taktik yang digunakan guru dalam proses pembelajaran di kelas.

Dengan adanya strategi mengajar akan memberikan kemungkinan yang tinggi dalam mempengaruhi keefektifan belajar peserta didik. Dalam praktiknya, guru dimungkinkan memberikan modifikasi perubahan dan mempengaruhi peserta didik untuk membantu keberhasilan peserta didik dalam belajar yang lebih baik. Hal tersebut sesuai dengan yang diungkapkan dalam sebuah artikel "The teaching strategies suggested have the high probability of effecting efeective learning in students. Practicing teachers may have to bring about some modifications, minor changes and adapt them to further increase the probability of their success in helping students learn more and bett" (Ravi Ranga Rao, 2004), (Strategi pengajaran yang disarankan memiliki probabilitas tinggi untuk mempengaruhi pembelajaran yang efektif pada siswa. Guru yang berlatih mungkin harus membawa beberapa modifikasi, perubahan kecil dan mengadaptasinya untuk lebih meningkatkan kemungkinan keberhasilan mereka dalam membantu siswa belajar lebih banyak dan lebih baik.)

Sehingga Strategi guru yang di maksud oleh peneliti dalam penelitian ini adalah langkah-langkah pembelajaran yang dilakukan oleh guru dalam pelaksanaan pembelajaran dan mengembangkan model pembelajaran yang sesuai. Strategi pembelajaran fokus pada apa yang dilakukan guru dan anak didik serta apa yang mereka lakukan tidak hanya pemberian dan penguasaan teori, tetapi juga memperhatikan kecakapan bagi anak didik.

Guru Pendidikan Agama Islam juga diharapkan memiliki berbagai strategi dalam pengajaran, terutama pembelajaran Al Qur'an. Guru harus mampu meningkatkan kemampuan peserta didik dalam membaca Al-Qur' an yang merupakan bagian dari materi Pendidikan agama Islam. Pembelajaran Al Qur'an merupakan materi penting yang harus diajarkan pada siswa, karena banyak manfaat dengan membaca Al Qur'an baik di dunia maupun di akherat kelak.

Dalam memberikan pengajaran Al-Qur'an ada dasar-dasar yang harus digunakan, karena Al-Qur'an adalah sumber dari segala sumber hukum bagi umat Islam yang mencakup segala aspek kehidupan manusia. Al-Qur'an adalah pedoman bagi manusia untuk menjalani kehidupannya di dunia akhirat kelak, diantara dasar dalam mempelajari Al-Qur'an adalah Surat Al-Alaq ayat 1-5

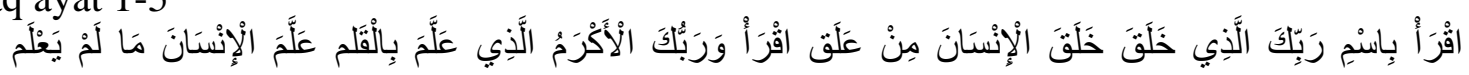

Artinya:"Bacalah dengan (menyebut) nama Tuhanmu yang Menciptakan. Dia telah menciptakan manusia dari segumpal darah. Bacalah, dan Tuhanmulah yang Maha pemurah. yang mengajar (manusia) dengan perantaran kalam. Dia mengajar kepada manusia apa yang tidak diketahuinya". Dalam ayat lain juga disebutkan : 


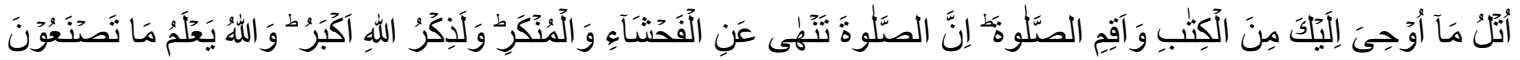

Artinya "Bacalah apa yang telah diwahyukan kepadamu, yaitu Al Kitab ( Al Qur'an) dan dirikanlah sholat. Sesungguhnya sholat itu mencegah dari perbuatan keji dan mungkar. Dan sesungguhnya mengingat allah ( sholat) adalah lebih besar (keutamaannya dari ibadah-ibadah yang lain). Dan Allah mengetahui apa yang kamu kerjakan. (QS.Al-Ankabut ayat 45)

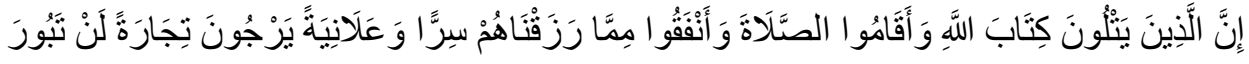

Terjemahnya: Sesungguhnya orang-orang yang selalu membaca kitab Allah (Al-Qur'an) dan melaksanakan shalat dan menginfakkan sebagian rezeki yang Kami anugerahkan kepadanya dengan diam-diam dan terang-terangan, mereka itu mengharapkan perdagangan yang tidak akan rugi. ( QS. Fatir/35 ayat 29 ). Ayat ini memberi pemahaman bahwa membaca Al-Qur'an memberikan pengaruh dalam kehidupan. Orang yang membaca Al-Qur'an dengan sempurna akan merasakan kelapangan dan mendapatkan kebaikan di dunia maupun di akhirat.

Selian bersumber pada Al-Quran pembelajaran Al-Quran juga bersumber dari hadist Nabi Muhammad SAW yang berbunyi:

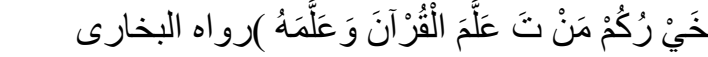
Artinya: "Sebaik-baiknya kamu adalah orang yang mempelajari Al-Qur'an dan mengajarkannya. (HR. Bukhari).

Pembelajaran Al-Qur'an, idealnya diberikan kepada anak sejak usia dasar. Hal ini ditujukan agar anak mampu memahami Al-Qur'an sejak dini dan menumbuhkan kecintaan anak terhadap Al-Qur' an. Oleh karena itu, pembelajaran Al-Qur' an tidak boleh jeda apalagi berhenti diberikan pada anak dalam situasi dan kondisi apapun, termasuk era pandemi covid-19 yang mewabah di dunia (Lubis et.al.2020).

Penggunaan teknologi sebenarnya bukan tanpa masalah, banyak faktor yang menghambat terlaksananya pembelajaran Daring. Sehingga secara tidak langsung sekolah dan guru dalam waktu singkat harus memikirkan strategi pembelajaran E-learning yang tepat dan sesuai dengan kebutuhan kurikulum. Guru di tuntut untuk mencari strategi dan teknik mengajar yang tepat serta harus melek teknologi dalam mencapai tujuan pendidikan.

Fokus permasalahan penelitian ini adalah ingin mengetahui proses pelaksanaan pembelajaran Al-Qur'an selama pandemi Covid-19 di SDN pada Gugus 8 Cakung Jakarta Timur mengenai strategi guru Pendidikan Agama Islam dalam pembelajaran Al-Qur'an melalui E-Learning, faktor pendukung dan kendala yang dihadapi serta solusi yang ditempuh oleh guru dalam pembelajaran Al-Qur'an melalui E-Learning.

Pada dasarnya ada banyak sekali metode, media, strategi pembelajaran yang dihasilkan oleh para peneliti dalam pembelajaran atau para ilmuwan dalam rangka agar proses pembelajaran berlangsung dengan baik dan tepat waktu sehingga tercapainya kompetensi yang telah ditetapkan dalam pembelajaran oleh satuan pendidikan atau penyelenggara pendidikan.

Strategi pembelajaran yang digunakan oleh guru di dalam pembelajaran Al-Qur'an pada masa pandemi covid 19 ini adalah strategi dengan memanfaatkan E-learning. Yaitu Strategi dengan pemanfaatan alat elektronik yang terakses internet ini dimaksudkan sebagai cara untuk menjelaskan sesuatu (bahan pelajaran) melalui alat-alat elektonik atau yang sering disebut dengan E-learning, strategi ini bertujuan untuk membantu guru dan peserta didik dalam melakukan proses pembelajaran, sehingga pembelajaran dapat dilakukan meskipun di masa covid 19, dengan keterbatasan ruang dalam bertatap muka, dan juga dapat membentuk siswa dalam memanfaatkan media elektronik berupa laptop atau ponsel sebagai alat untuk melakukan proses pembelajaran.

Sehingga hal ini harus menjadi perhatian dan pemikiran oleh guru dalam pembelajaran adalah untuk dapat mengatasi masalah dalam melakukan pembelajaran melalui E-learning. Mencari faktor penyebab, mencari solusi pemecahan masalah yang dihadapi. Guru juga mengupayakan perbaikan dengan penerapan inovasi pembelajaran untuk mengembangkan 
proses pembelajaran yang lebih baik lagi sehingga dapat mencapai tujuan pembelajaran yang telah ditetapkan secara maksimal.

\section{METODE PENELITIAN}

Metode yang digunakan pada penelitian ini adalah metode penelitian kualitatif diskritif, yakni penelitian yang menghasilkan data deskriptif berupa kata-kata tertulis atau lisan dari orang-orang dan perilaku yang dapat diamati Berdasarkan fokus dan tujuan penelitian, maka penelitian ini merupakan kajian yang mendalam guna memperoleh data yang lengkap dan terperinci. Penelitian ini bertujuan untuk mendapatkan gambaran mendalam mengenai terhadap pelaksanaan pembelajaran Al-Qur'an melalui E-learning di masa Pandemik. Pendekatan kualitatif menurut Best, seperti yang dikutip Sukardi adalah metode penelitian yang berusaha menggambarkan dan menginterpretasikan objek sesuai dengan apa adanya. Pengumpulan data dalam penelitian ini dimaksudkan untuk memperoleh bahan-bahan, keterangan, kenyataankenyataan dan informasi yang dapat dipercaya. Untuk memperoleh data seperti prosedurprosedur, alat-alat serta kegiatan nyata, penulis menentukan teknik pengumpulan data yang melalui observasi, wawancara dan dokumentasi.

Sumber data dalam penelitian ini dibagi menjadi dua yaitu sumber data primer dan sumber data sekunder. Sumber data primer adalah sumber data yang langsung memberikan data kepada pengumpul data. Sumber data primer adalah guru pendidikan agama Islam yang berjumlah 15 guru untuk mengetahui bagaimana proses yang dilakukan dalam pelaksanaan pembelajaran Al-Quran melalui E-learning. Sedangkan sumber data sekunder adalah data yang diperoleh langsung dari pihak-pihak yang berkaitan yaitu ketua Gugus 8, Kepala Sekolah SDN pada Gugus 8 Cakung Jakarta Timur,

Teknik analisis data pada penelitian ini berpedoman pada langkah-langkah yang dikemukakan oleh Miles dan Huberman (Sugiyono : 2017) yaitu yang digunakan dalam analisis data kualitatif terdiri dari tiga langkah yaitu Reduksi data, penyajian data dan penarikan kesimpulan.

\section{HASIL DAN PEMBAHASAN}

Hasil

Setelah peneliti melakukan observasi, wawancara dan dokumentasi secara mendalam ke beberapa sekolah negeri pada Gugus 8 di Cakung Jakarta Timur, maka diperoleh hasil yang menunjukkan bahwa strategi para guru pendidikan agama islam dalam pembelajaran Al-Qur'an secara E-Learning dapat terlaksanan secara efektif dan fleksibel. Hasil penelitian dianggap sesuai dengan fokus masalah dalam penelitian sebagai berikut :

Guru sangat mendukung penggunaan E-learning pada saat proses pembelajaran, karena dinilai dapat memudahkan proses belajar mengajar saat ini. Sesuai dengan yang diungkapkan oleh ibu Sri Rahayu Purwaningsih, Kepala sekolah SDN Pulo Gebang 07 bahwa: "Kita para pendidik tentunya sangat berusaha bagaimana supaya pembelajaran dapat tetap dilaksanakan sebaik mungkin, dan alhamdulillah di jaman serba komputer saat ini banyaknya aplikasi-aplikasi yang mendukung pembelajaran, sehingga banyak guru yang kreatif membuat video-video pembelajaran yang mudah untuk dipahami oleh anak didik"

Namun pada masa pandemi covid-19 yang sudah 3 semester ini ada program kegiatan keagamaan tidak terlaksana semua secara sempurna seperti tahun-tahun sebelumnya. Hal tersebut sesuai dengan yang disampaikan oleh ibu Suryanih: "Tidak semua progran kegiatan keagamaan dilaksanakan pada masa pandemi ini, hanya kegiatan tadarus saja melalui zoom meeting dan video call, Pengisian agenda Ramadhan harian melalui google form, dan Ramadhan Ceria melalui kegiatan pembelajaran, perlombaan yang diikuti melalui kegiatan virtual dan pengiriman video".Hal senada juga disampaikan oleh ibu Widya, bahwa bayak program kegiatan baik yang kegiatan umum atau ekstrakurikuler ataupun kegiatan keagamaan yang tidak dapat laksanakan seperti pramuka, PMR, loketa, pentas seni islam, namun masih ada yang bisa dilaksanakan walaupun bentuknya sederhana dan secara virtual. 
Pernyataan diatas diperkuat oleh bapak Rohim selaku Guru PAI SDN Pulo Gebang 06 dan guru lainnya, beliau menyatakan bahwa, "Banyak kegiatan keagamaan tidak dapat kita dilaksanakan pada saat ini, seperti lomba ketrampilan Agama ( Loketa) baik antar gugus ataupun antar wilayah, maulid Nabi, pawai Tahun Baru Islam yang bisanya kita laksanakan bersama gabungan sekolah-sekolah satu gugus 8 . Dan untuk kegiatan tadarus dan ceramah agama yang bisanya dilaksanakan bersama dengan sekolah lain yang satu halaman sekolah juga tidak dapat dilaksanakan.

Pembelajaran Al-Qur'an merupakan suatu proses pembelajaran yang meliputi membaca, menulis, dan menghafal serta aspek-aspek pembelajaran seperti Tajwid, Qira'at dan Maharijul huruf. Guna menjadikan sebagai sumber belajar bagi anak didik di SDN pada gugus 8 Cakung Jakarta Timur, untuk mengarahkan anak didik kepada kemampuan membaca, menulis, menghafal, memahami dan menghayati Al-Qur'an menjadikan sebagai kitab sucinya. Sebagaimana disampaikan oleh bapak Mubarok guru Pendidikan agama islam di SDN Pulo gebang 07. Hal tersebut sama juga yang disampaikan oleh ibu Suryanih dan guru lainnya. 'Dalam pembelajaran Al-Qur'an tentunya banyak yang kita ajarkan sesuai dengan materi pembelajran Al-Qur'an seperti mengenalkan huruf-huruf hijaiyyah, mengenalkan tanda baca, cara membaca yang benar, hukum tajwidnya dan juga menghafalkan ayat-ayat Al-Qur'an, serta kita sampaikan juga kandungan dan makna dari suatu ayat Al-Qur'an."

Dari penjelasan diatas maka dapat katakan bahwa pembelajaran Al-Quran akan disesuaikan dengan materi dan kemampuan setiap anak, mulai dari mengenalkan huruf hijaiyyah, cara mengucapkannya, cara membaca yang benar sesuai dengan hukum tajwid, dan juga pemberian tugas anak didik untuk menulis dan menghafalkan ayat-ayat 1-Qur'an.

Hasil dari penelitian ini menemukan bahwa strategi yang digunakan guru dalam pembelajaran agama khususnya dalam pembelajaran Al-Qur'an adalah dengan menggunakan aplikasi Whatsapp baik secara pesan tertulis (chat), pesan suara (voicenote), panggilan suara (video call), membuat vidio, pengiriman video-video pembelajaran dari youtube serta tatap muka maya (Virtual) melalui zoom meeting. Hal tersebut sesuai yang disampaikan oleh Bapak Mubarok."Pelaksanaan pembelajaran saat pandemi ini kita banyak menggunakan dengan aplikasi video, whatsapp group, ataupun kadang dengan zoom. Dan pelaksanaan pembelajaran dengan waktu yang sedikit namun harus bisa efektif, begitu pula pembelajaran Al-Qur'an ada dalam pembelajaran pendidikan agama islam, jadi dalam pelaksanaannya setiap minggu pada saat pelajaran Agama Islam ada pembelajaran Al-Qur'an, karena sebelum dimualai guru sudah mempersilahkan peserta didik untuk melaksanakan sholat dhuha, dan tadarus Al-Qur'an lalu masuk ke materi pelajaran yang sudah kita siapkan, lalu anak mengerjakan tugas, setelah selesai anak mendokumentasikan kegiatannya dan mengirim foto kegiatannya ke guru."

Hal senada juga disampaikan oleh- guru-guru yang lain bahwa pembelajaran Al-Quran diterapkan setiap akan memulai pembelajaran guru mengirimkan Video tilawah/bacaan AQur'an dan anak didik menyimak bacaan tersebut. Setelah anak didik menyimak, lalu guru akan melakukan videocall melalui Whatsaap satu persatu anak untuk membacakan kembali ayat-ayat Al-Quran yang tadi ditampilkan. Hal tersebut sesuai dengan yang disampaikan oleh ibu bapak Abdul Rohim,"Pada pembelajaran Al-Qur'an dilakukan setiap memulai kegiatan belajar diawali dengan tadarus Al-Qur'an bersama secara zoom, lalu satu persatu anak membacakan ayat-ayat Al-Qur'an dan teman lainnya menyimak bacaan tersebut, atau kadang kita kirimkan vidio bacaan ayat-ayat Al-Qur'an untuk ditampilkan dan mendengarkan bacaan Al-Qur'an yang baik dan benar, kemudian guru menujuk beberapa anak didik yang akan di video call melalui whatsapp untuk membacakan ulang ayat-ayat yang tadi di tampilkan."

Pembelajaran Al-Quran selain membaca anak didik tentunya ada juga kegiatan untuk menghafal ayat-ayat Al-Qur'an, untuk anak didik kelas satu sampai kelas tiga yang belum bisa membaca Al-Qur'an, dengan adanya kegiatan tadarus bersama membaca surat-surat pendek sebelum belajar akan membuat anak didik hafal surat-surat tersebut, yakni menghafal suratsurat pendek dari surat Al Fatehah, surat An naas, Al falaq, Al ikhlas dan seterusnya. Untuk kelas tinggi selain surat-surat pendek juga menghafal surat-surat yang sesuai dengan materi 
pembelajaran. Contohnya pada materi kelas 6 untuk menghafal QS Al-Hujurot ayat 13. Sebelumnya guru memberikan materi tentang kandungan dan makna dari ayat tersebut, lalu memberikan tugas pada anak didik untuk menghafalkan ayat tersebut dan menyetorkan hafalannya pada minggu depannya dengan video call atau membuat rekaman video bacaan hafalannya. Hal tersebut sesuai dengan yang disampaikan oleh bapak Mubarok yang menyatakan bahwa: "Dalam pembelajaran Al-Quran selain belajar mengenal huruf Hijaiyyah, membaca yang benar, mengenal hukum tajwidnya, dan menuliskannya, anak-anak juga menghafalkan surat-surat pendek. Setiap akan memulai kegiatan belajar kita membaca tadarus surat-surat pendek dari surat Al Fatehah, An naas dan seterusnya, itu sangat membantu anak didik untuk hafal surat-surat pendek, dan untuk kelas 4,5, dan 6 selain surat-surat pendek mereka juga menghafalkan surat-surat pilihan sesuai dengan materi pembelajaran, contohnya untuk kelas 6 yang menghafalkan surat Al maidaah ayat 12-13 dan surat Al Hujurot ayat 13."

Hasil dari penelitian ini strategi yang digunakan dalam pembelajaran agama khususnya dalam pembelajaran Al-Qur'an adalah dengan menggunakan aplikasi Whatsapp baik secara pesan tertulis (chat), pesan suara (voicenote), panggilan suara (video call), membuat vidio, pengiriman video-video pembelajaran dari youtube serta tatap muka maya (Virtual) melalui zoom meeting. Pembelajaran dilaksanakan melalui whatsapp group kelas, dengan menggunakan whatsapp kita dapat melakukan obrolan online, bisa berbagi informasi, kirim video pembelajaran, kirim foto dan lainnya.

Pada penelitian ini berdasarkan hasil wawancara terhadap guru Pendidikan Agama Islam, guru merupakan faktor yang paling penting dalam pelaksanaan pembelajaran, karena guru yang menentukan materi dan metode yang diterapkannya. Sehingga guru harus mampu penggunakan teknologi komputer dan dapat mengakses internet. Hal tersebut sesuai yang diungkapkan ibu Sri Rahayu, beliau mengungkapkan bahwa:

"Dalam pelaksanaan pembelajaran saat ini yah gurulah yang menentukan metode ataupun materi yang akan digunakan, karenanya guru harus mempunyai kemampuan yang baik dalam pemakaian perangkat komputer atau handphone dengan android. Dengan adanya teknologi yang maju saat ini guru lebih mudah mencari materi-materi pembelajaran yang akan digunakan dan diberikan pada anak didik disesuaikan dengan kelas dan tujuan pemebelajannya. Masalahnya jika guru atau anak didik gaptek atau gak bisa menggunakan teknologi, tidak bisa mengoperasikan laptop atau handphone secara baik, ini menjadi kendala dalam pembelajaran E-learning. Makanya kita berikan pelatihan untu para guru bagaimana menggunakan laptop ataupun handphone untuk pembelajaran."

Pernyataan diatas dibenarkan oleh beberapa guru lainnya bahwa keberadaan media ponsel atau laptop sangat mendukung pelaksanaan pembelajaran saat ini, anak didik bisa belajar tidak terpaku dengan waktu, kapan anak siap dan tersedianya media tersebut dia bisa mengerjakan tugas pembelajaran dari guru.

Faktor pendukung lainnya dalam pelaksanaan pembelajaran Al-Qur'an melalui Elearning, yang didapat dari hasil penelitian ini adalah kemampuan dan kemauan dari guru dan anak didik dalam melakukan pembelajaran. Hal tersebut sesuai dengan yang disampaikan oleh bapak Rohim bahwa walaupun belajar di rumah melalui elearning anak didik dapat mengikuti dengan senang karena mereka merasa senang dan enjoy dalam penggunaan ponsel untuk pemebelajaran. Peernyataan tersebut dibenarkan oleh ibu Suryanih, beliau menyatakan' "Alhamdulillah anak-anak merasa senang bisa belajar dirumah melalui E-learning dengan menggunakan handphone, karena waktu belajarnya lebih singkat dan mereka bisa melihat materi-materi yang disampaikan oleh guru melalui video-video pembelajaran yang lebih bervareasi dan menerik."

Dukungan dan bimbingan orangtua ataupun anggota keluarga lain juga salah satu pendukung pembelajaran secara E-Learning. Hal tersebut sesuai dengan yang disampaikan oleh ibu Widya bahwa peran orangtua atau keluarga sangat membantu dalam pelaksanaan pembelajaran melalui E-learning saat ini, tanpa bimbingan dan pendampingan orangtua anak 
kurang faham dan kurang fokus pada pembelajaran. Pernyataan diatas diperkuat oleh pernyataan bapak Syarif , beliau menyatakan bahwa

"Dalam pelaksanaan pembelajaran melalui E-learning ini khususnya dalam pembelajaran $\mathrm{Al}$ Qur'an kita sangat perlu adanya kerjasama dengan wali murid atau keluarga anak didik, karena anak harus banyak mengulang pembelajaran Al-Quran, dengan banyak membaca dan mengulang-ulang bacaan Al-Qur'an di rumah.

Faktor pendukung lainnya dalam pembelajran A-Qur'an melalui E-learning adalah anak didik mengikuti pengajian atau Taman Pendidikan Al-Qur'an (TPA) dilingkungan rumahnya, Hal tersebut disampaikan oleh bapak Rohim dan guru-guru lainnya dan diperkuat oleh pernyataan ibu Suryanih, beliau menyatakan bahwa :

"Bagi anak didik yang dirumahnya mengikuti TPA atau pengajian dirumahnya akan cepat memahami pembelajaran Al-Qur'an melalui e-learning baik bacaannya ataupun hafalan AlQuran. Karena bisa tiap hari atau sepekan tiga kali ia belajar di TPA atau pengajian, semakin sering dia mengaji maka akan semakin lancar dia membaca Al-Qur'an. Berbeda dengan anak yang tidak mengikuti TPA atau pengajian dirumaahnya dan hanya mengandalkan pembelajaran disekolah itupun sepekan sekali, maka akan lama keberhasilan anak untuk bisa membaca AlQur'an."

Pada penelitian ini juga ditemukan juga adanya kendala atau faktor penghambat yang dihadapi oleh guru untuk pembelajaran Al-Quran secara E-learning, diantaranya adalah dari kurangnya media untuk pembelajaran yakni komputer atau ponsel android dan juga akses internet. Hal tersebut disampaikan oleh ibu Suryanih, baliau menyatakan :

"Kendala yang dihadapi dalam pembelajaran E-learning adalah adanya beberapa anak yang tidak memiliki komputer atau handphone android, dalam satu keluarga Cuma ada satu handphone milik orangtuanya, dan orangtuanya harus kerja, sehingga anak tidak bisa mengikuti pembelajaran jika ada zoom atau pembelajaran bersama on line, sehingga anak tidak bisa langsung mengerjakan tugas. Ada juga anak memiliki handphone tapi tidak ada kuota, sehingga anak tidak bisa mengikuti pembelajaran, nunggu diisi kuota internet."

Hal senada disampaikan oleh ibu widya bahwa kendala yang dihadapi dalam pembelajaran E-learning adalah anak tidak memiliki ponsel sehingga memakai punya orangtuanya, atau bergantian pemakaiannya dengan kakaknya yang juga harus belajar secara online. Jika orangtuanya kerja dan ponselnya dibawa oleh orangtuanya, maka ia tidak dapat mengikuti pelajaran, dan akan mengerjakaan tugas pada sore atau malam hari setelah orangtuanya sampai di rumah.

Faktor penghambat lainnya adalah dalam pembelajaran Al-qur'an secara E-learning adalah penilaian atau pengevaluasian hasil belajar tidak bisa langsung selesai. Seperti yang disampaikan oleh ibu Novi bahwa Pegumpulan tugas anak didik tidak bisa serentak karena waktu anak didik membuka materi dan pengumpulan tugas berbeda-beda meskipun sudah di beri jangka waktu. Dan solusi yang terapkan pada anak didik adalah membatasi waktu dalam pengumpulan tugas, dan memberikan perpanjangan waktu pengumpulan tugas pada anak didik yang memang tidak memiliki media sendiri.

Dari beberapa uraian wawancara diatas, seta observasi, maka peneliti menyimpulkan bahwa adanya kendala-kendala yang dihadapi oleh guru dalam pelaksanaan pembelajaran AlQuran melalui E-learning, diantaranya kepemilikan ponsel atau laptop dan jaringan internet, kemampuan dan kemauan guru atau anak didik dalam pembelajaran, dukungan dan bimbingan dari orangtua dan anggota keluarga, serta keikutsertaan anak dalam pembelajaran diluar sekolah seperti pada TPA atau pengajian lainnya.

\section{Pembahasan}

1. Strategi Guru Pendidikan Agama Islam dalam pembelajaran Al-Qur'an melalui ELearning di SDN pada Gugus 8 Cakung Jakarta Timur.

Makna umum strategi mempunyai pengertian sebagai suatu garis-garis besar haluan untuk bertindak dalam usaha untuk mencapai sasaran yang telah ditentukan. Dihubungkan 
dengan pembelajaran, strategi dapat diartikan sebagai pola-pola umum kegiatan guru terhadap peserta didik dalam mewujudkan kegiatan pembelajaran untuk mencapai tujuan yang telah digariskan (Syaiful Bahri Djamarah, 2006).

Strategi guru dalam pembelajaran dengan menggunakan E-learning pada masa pandemi covid-19 saat ini merupakaan suatu usaha yang dilakukan oleh semua guru tak terkecuali guru pendidikan agama islam dalam memberikan pembelajaran Al-Qur'an, hal tersebut sesuai dengan kebijakan yang di keluarkan oleh Mentri Pendidikan bahwa semua kegiatan pembelajaran dimasa pandemi covid-19 dilakukan dirumah secara daring atau E-learning, sebagaimana penelitian sebelumnya yang dilakukan oleh Torikhul Wasyik, Abdul Hamid. Universitas Islam Negeri Sunan Ampel Surabaya, Indonesia

Hasil dari penelitian ini dapat katakan bahwa pembelajaran Al-Quran akan disesuaikan dengan materi dan kemampuan setiap anak, mulai dari mengenalkan huruf hijaiyyah, cara mengucapkannya, cara membaca yang benar sesuai dengan hukum tajwid, dan juga pemberian tugas anak didik untuk menulis dan menghafalkan ayat-ayat Al-Qur'an.

Dalam pelaksanaan pembelajaran pada dasarnya merupakan pelaksanaan dari perencanaan yang telah dibuat sebelumnya. Dalam pelaksanaan itu menunjukkan penerapan langkah-langkah suatu pendekatan atau strategi pembelajaran yang ditempuh untuk menyediakan pengalaman belajar dengan mengoptimalkan pembelajaran yang efektif untuk mencapai keberhasilan dari tujuan pembelajaran, dan mengelola kegiatan pembelajaran dapat terselesaikan dengan waktu yang tepat. Sebagaimana yang diungkapkan pada penelitian sebelumnya oleh Fitria Nur Bayti, bahwa Hasil penelitian tersebut menunjukkan bahwa peran guru Al-Qur'an Hadits memberikan pengajaran terhadap siswa dengan menggunakan langkahlangkah yaitu menentukan tujuan yang ingin dicapai, menentukan materi, menentukan metode, memberikan tugas kepada siswa, memberikan dorongan agar siswa belajar dengan sungguhsungguh dan memberikan nasihat.

Pada penelitian ini menghasilkan temuan bahwa strategi guru dalam pembelajaraan AlQuran melalui E-learning di SDN pada gugus 8 di Cakung, yakni langkah-langkah pembelajaran Al-Qur'an dengan menggunakan aplikasi Whatsapp dan aplikasi Zoom Meeting. Adapun pembelajaran dengan aplikasi Whatsapp dengan langkah-langkah sebagai berikut :

a. Mengkondisikan anak didik siap untuk siap belajar dengaan melakukan absensi kehadiran.

b. Melakukan tadarus Al-Qur'an setiap memulai pembelajaran.

c. Mengirimkan materi pembelajaran dalam bentuk vidio pembelajaran.

d. Melakukan evaluasi dengan melakukan videocall atau zoom.

e. Memotivasi anak didik dengan memberikan hadiah pada anak didik yang dapat menghafalkan beberapa surat tertentu.

f. Pernyataan kerjasama dengan orangtua untuk membimbing dan membantu anak didik juka mengalami kesulitan belajar.

Sedangkan pembelajaran Al-Quran melalui E-learning dengan menggunakan aplikasi

Zoom Meeting dengan Langkah-langkah sebagai berikut :

a. Melakukan absensi kehadiran anak didik

b. Tadarus bersama

c. Pembukaan pembelajaran

d. Penjelasan materi pelajaran

e. Pemberian tugas dari materi pembelajaran

f. Memotivasi anak didik dengan cerita hikmah atau memberikan hadiah pada anak didik yang mencapai target yang ditetapkan guru.

g. Pernyataan kerjasama dengan orangtua untuk membimbing dan membantu anak didik jika mengalami kesulitan belajar.

\section{Faktor Pendukung dalam Strategi Guru dalam Pembelajaran Al-Qur'an di SDN pada Gugus 8 Cakung Jakarta Timur}




\section{EDUCATIONAL : Jurnal Inovasi Pendidikan dan Pengajaran Vol. 2 No. 1 Februari 2022 e-ISSN : 2775-2593 | p-ISSN : 2775-2585}

Guru merupakan faktor yang paling penting dalam pelaksanaan pembelajaran, karena gurulah yang mengelola proses pembelajaran untuk berjalan secara efektif dan efesien. Begitupun dalam pelaksanaan pembelajaran Al-Qur'an melalui E-learning, guru yang menentukan materi dan metode yang diterapkannya. Sehingga guru harus mampu penggunakan teknologi komputer dan dapat mengakses internet.

Berdasarkan hasil temuan pada penelitian ini menunjukkan bahwa fator pendukung dalam strategi guru dalam pembelajaran Al-Qur'an melalui E-learning di SDN pada gugus 8 Cakung adalah :

a. Tersedianya sarana atau media yang memadai baik pada guru maupun anak didik. Sarana yang diperlukan untuk pembelajaran E-learning adalah perangkat komputer atau ponsel android dan akses internet, dan tentunya kemampuan untuk menggunakan alat tersebut.

$b$. Guru menguasai materi dan juga menguasai teknologi. karena dengan penguasaan teknologi komputer guru akan banyak menemukan media dan materi pembelajaran baik berupa videovideo pembelajaran maupun artikel-artikel yang terkait dengan pembelajaran yang dapat di gunakan dalam pembelajaran melalui E-learning.

c. Kemampuan dan kemauan dari guru dan anak didik dalam melakukan pembelajaran. Karena sejak pandemi ini anak didik berada dirumah, sehingga merasa bosan berada dirumah, tidak bisa bertemu dengan teman, tidak bisa bermain, namun adanya kemauan dan kemampuan dalam belajar menggukan media baik ponsel atau laptop dengan baik, sehingga ia bisa mengikuti pembelajaran E-learning dengan baik.

d. Kerjasama dan dukungan dari keluarga baik orangtua ataupun anggota keluarga lainnya. Dukungan tersebut berupa pendampingan dan bimbingan orangtua pada anak didik dalam pembelajaran, khususnya pembelajaran Al-Qur'an.

e. Anak didik mengikuti pengajian atau Taman Pendidikan Al-Qur'an (TPA) dilingkungan rumahnya diluar jam sekolah, sehingga anak didik akan semakin sering berinteraksi dengan Al-Qur'an, baik membaca, menulis, maupun menghafal Al-Qur'an.

\section{Kendala yang dihadapi dan Solusi yang ditempuh dalam Pembelajaran Al-Qur'an melalui E-Learning di SDN pada Gugus 8 Cakung Jakarta Timur}

Dalam pembelajaran daring akan ditemukan suatu kendala, yaitu kurangnya pemahaman siswa ketika melakukan proses belajar daring. Hal ini sesuai dengan hasil penelitian yang dilakukan oleh Muhamad Suhardi dkk (2021) bahwa kendala yang dihadapi dalam pembelajaran daring di dikarenakan siswa kurang paham dengan pembelajaaran yang diajarkan oleh guru karena tidak bertatap muka langsung dan guru sulit memantau perkembangan belajar siswa. Faktor utama yang lebih penting lagi adalah kurangnya fasilitas yang dimilki oleh siswa ketika belajar daring karena tidak semua siswa memiliki Smarthphone ataupun komputersebagai media pembelajaran menggunakan daring. Selain itu faktor lain adalah paket internet yang tidak bisa dijangkau oleh semua siswa.

Pada penelitian ini ditemukan adanya kendala atau faktor penghambat yang dihadapi oleh guru untuk pembelajaran Al-Quran secara E-learning, diantaranya adalah:

a. Kurangnya media untuk pembelajaran yakni komputer atau ponsel android dan juga akses internet. Terdapat anak yang tidak memiliki ponsel atau laptop serta jaringan internet. Sehingga anak didik tidak dapat mengikuti pembelajaran secara bersama pada jam sekolah baik secara tatap muka maya (zoom) atau online, solusi yang diterapkan oleh guru adalah menyarankan anak didik untuk bergabung bersama teman sekolahnya yang siap belajar secara online.

b. Penilaian atau pengevaluasian hasil belajar tidak bisa langsung selesai, karena pengerjaan dan pengumpulan tugas ada yang tidak tertib atau cenderung menjadi semakin molor. Pegumpulan tugas anak didik tidak bisa serentak karena waktu anak didik membuka materi dan pengumpulan tugas berbeda-beda meskipun sudah di beri jangka waktu. Adapun solusi yang diterapkan pada anak didik adalah membatasi waktu dalam 
pengumpulan tugas, dan memberikan perpanjangan waktu pengumpulan tugas pada anak didik yang memang tidak memiliki media sendiri.

c. Terdapat anak yang lambat untuk memahami pembelajaran Al-Quran karena tidak mau mengulang-ulang atau kurangnya bimbingan dari orangtua atau anggota keluarga dalam pembelajaran Al-Qur'an dirumah. Solusi yang kita terapkan adalah minta kerjasamanya dengan orangtua anak didik untuk memberikan bimbingan dalam pembelajaran AlQur'an dirumah dengan untuk mengikutkan anak pada pengajian atau Taman Pendidikan Al-Qur'an (TPA) dilingkungan tempat tinggal pada waktu di luar jam sekolah.

\section{KESIMPULAN}

Berdasarkan hasil analisis data dan pembahasan dari wawancara, observasi dan dokumentasi yang dilakukan, maka penulis mengemukakan beberapa kesimpulan dan saran yang berkenaan dengan strategi guru dalam pembelajaran Al-Qur'an melalui E-learning di SDN pada Gugus 8 Cakung Jakarta Timur adalah sebagai berikut:

1. Mempelajari A-Qur'an merupakan sebuah kewajiban sebagai seorang muslim juga merupakan program wajib yang dilakukan oleh seluruh peserta didik dari kelas 1 hingga kelas 6 di Sekolah Dasar. Proses pelaksanaannya dilakukan secara bersama-sama disekolah. Namun kegiatan ini terhenti sejak pemerintah memberlakukan pembelajaran secara online. Sehingga guru Pendidikan Agama Islam berupaya untuk membuat sebuah strategi pembelajaran Al-Quran melalui media online atau E-learning, yakni pembelajaran yang mampu membuat peserta didik pada masa ini untuk dapat secara optimal menggunakan potensi yang dimilikinya sehingga proses pembelajaran dapat semaksimal mungkin terlebih masa Pandemi Covid-19 saat ini.

2. Strategi guru dalam pembelajaran Al-Qur'an melalui E-learning di SDN pada Gugus 8 Cakung Jakarta Timur merupakan langkah-langkah yang digunakan oleh guru dalam pelaksanaan pembelajaran Al-Quran melalui pembelajaran jarak jauh dengan pemanfaatan teknologi melalui aplikasi-aplikasi yang tersedia dalamnya. Kegiatan pembelajaran yang digunakan guru untuk pembelajaran Al-Qur'an melalui E-learning dilaksanakan dengan menggunakan aplikasi Whatsapp baik secara pesan tertulis (chat), pesan suara (voicenote), panggilan suara (video call), membuat vidio, pengiriman videovideo pembelajaran dari youtube serta tatap muka maya (Virtual) melalui zoom meeting.

\section{DAFTAR PUSTAKA}

Ahmad Sabri. 2005. Strategi Belajar Mengajar dan Micro Teaching. Jakarta: Quantum Teaching

Departemen Agama RI. 2006. Al-Qur'an dan Terjemahnya. Semarang: PT. Toha Putra

Imam Abi Abdillah Muhammad bin Ismail Al-Bukhari. 1994. Shahihul Bukhari. Beirut: Darul Fikri

Irawan Prasetya. 1999. Logika dan Prosedur Penelitian : Pengantar Teori dan Panduan Praktis Penelitian Sosial bagi Mahasiswa dan Peneliti Pemula. Jakarta: STAIN

Lubis Rahmat rifai et.al. 2020. Pembelajaran Al Qur'an era Covid-19. Kuttab. Jurnal Ilmu Pendidikan Islam, Vol 04 no 02

Margono. 2010. Metodologi Penelitian Pendidikan. Jakarta: Rineka Cipta

Muhadjir Noeng. 2007. Metodologi Keilmuan: Paradigma Kualitatif, Kuantitatif, dan Mixed. Yogyakarta: Rake Sarasin

Muhamad suhari, Haromain, Wida safitri. (2021). Pendekatan Ramah Anak Dalam meningkatkan Motivasi Belajar Siswa Pada Masa Pandemi covid-19 Di SDN Kilang Kabupaten Lombok Timur. Cendikia : Jurnal Ilmu Penegtahuan, Vol 1 no 3

Ravi Ranga Rao. 2004. Methods of Teacher Training. New Delhi: Discovery Publishing House Sardiman A.M. 1990. Interaksi dan Motivasi Belajar Mengajar. Jakarta: Raja Grafindo

Sukardi. 2005. Metode Penelitian Pendidikan: Kompetensi dan Prakteknya. Jakarta: Bumi Aksara 
Surat Edaran Mendikbud Nomor 4 Tahun 2020 tentang Pelaksanaan Kebijakan Pendidikan dalam Masa Darurat Penyebaran Covid-19.

Syaiful Bahri Djamarah dan Aswan Zain. 2006. Strategi Belajar Mengajar. Cet. III; Jakarta:Rineka Cipta

Wina Sanjaya. 2005. Pembelajaran Dalam Impementasi Kurikulum Berbasis Kompetensi. Jakarta:Kencana Prenada Media group 